\title{
Cases of albinism and leucism in amphibians in Italy: new reports
}

\author{
Enrico Lunghi ${ }^{1-3^{*}}$, Alessandro Monti ${ }^{4}$, Arturo Binda ${ }^{5}$, Ionne Piazzi ${ }^{6}$, \\ Maurizio Salvadori ${ }^{7}$, Roberto Cogoni ${ }^{8}$, Luigi Andrea Riefolo, \\ Carlo Biancardi ${ }^{10-11}$, Sergio Mezzadri ${ }^{12}$, Domenico Avitabile ${ }^{13}$, \\ Gentile Francesco Ficetola ${ }^{13-15}$, Manuela Mulargia ${ }^{16}$, Salvatore Manca ${ }^{17}$, \\ Pauline Blaimont ${ }^{18}$, Anna Rita Di Cerbo ${ }^{10}$, Raoul Manenti ${ }^{13}$
}

\begin{abstract}
Findings of abnormally pigmented amphibian individuals provide interesting insights on intraspecific phenotypic variability as well as on variation among populations inhabiting different habitats. Amphibian coloration is determined by chromatophores (specific epidermal cells), and a variety of abnormalities related to them have been reported. In this study we reported cases of albinism and leucism in six species of Italian amphibians, including some endemic species. For
\end{abstract}

${ }^{1}$ Universität Trier Fachbereich VI Raum-und Umweltwissenschaften Biogeographie, Campus I, Gebäude N Universitätsring 15, 54286 Trier, Germany

${ }^{2}$ Museo di Storia Naturale dell'Università di Firenze, Sezione di Zoologia "La Specola", Via Romana 17, 50125 Firenze, Italia.

${ }^{3}$ Natural Oasis, Via di Galceti 141, 59100 Prato, Italia.

${ }^{4}$ Studio Professionale Tu.G.A., Rovello Porro, Italia.

${ }^{5}$ Associazione Le Contrade Onlus, Inverigo, Italia.

${ }^{6}$ Via Martesana 12, Gravedona ed Uniti, Italia.

7 Parco Naturale Paneveggio Pale di San Martino, Primiero San Martino Di Castrozza, Italia.

${ }^{8}$ Unione Speleologica Cagliaritana, Quartu Sant'Elena (CA), Italia.

${ }^{9}$ Dipartimento di Scienze dei Materiali, Università degli Studi di Milano Bicocca, Milano, Italia.

${ }^{10}$ C.S. Fauna Vertebrata "L. Cagnolaro", Società Italiana di Scienze Naturali, Milano, Italia.

${ }^{11}$ Department of Biological Sciences, CenUR L.N., Universidad de la República, Paysandú, Uruguay.

${ }^{12}$ Museo Civico di Storia Naturale di Piacenza, Via Scalabrini, 107, 29121 Piacenza, Italia.

${ }^{13}$ Dipartimento di Bioscienze, Università degli Studi di Milano, Via Celoria 26, 20133 Milano, Italia.

${ }^{14}$ Université Grenoble-Alpes, Laboratoire d'Ecologie Alpine (LECA), 38000 Grenoble, France.

${ }_{15}$ Centre National de la Recherche Scientifique, Laboratoire d'Ecologie Alpine (LECA), F-38000 Grenoble, France.

${ }^{16}$ Via Isalle 4, 08029 Siniscola, Italia.

${ }^{17}$ Speleo Club Nuoro, Via Tunisi 3, 08100 Nuoro, Italia.

${ }^{18}$ University of California, Santa Cruz 1156 High Street, Santa Cruz, CA 95060, USA.

* Corresponding author: enrico.arti@gmail.com

(C) 2017 Enrico Lunghi et alii

Received: 10 October 2016

Accepted for publication: 12 February 2017 some taxa, like Hydromantes sarrabusensis, H. flavus, H. supramontis and Bufo viridis, we describe the first observations of albinism and leucism.

Key words: Speleomantes, Rana, newt, Salamandra, chromatophores, tadpoles.

Riassunto - Casi di albinismo e leucismo negli anfibi in Italia: nuove osservazioni.

Studi sulla pigmentazione anomala degli anfibi forniscono spunti interessanti sulla loro variabilità fenotipica intraspecifica e sulla variazione tra popolazioni che abitano diversi habitat. La colorazione degli anfibi è determinata dai cromatofori (specifiche cellule epidermiche) e in letteratura vengono segnalate diverse anomalie relative a queste specifiche cellule. In questo studio abbiamo descritto casi di albinismo e leucismo in sei specie italiane di anfibi, tra cui alcune endemiche. Per alcuni taxa, come Hydromantes sarrabusensis, H. flavus, H. supramontis e Bufo viridis, descriviamo per la prima volta osservazioni di albinismo e leucismo.

Parole chiave: Speleomantes, Rana, tritoni, Salamandra, cromatofori, girini.

\section{INTRODUCTION}

Abnormal or uncommon colourations of amphibian specimens have historically interested herpetological literature and are often described and reported, especially in older texts (e.g. Capanna \& Foresti, 1974; Vanni \& Zuffi, 2001; Barbagli \& Violani, 2004). Such aberrations consist of unusual colouration caused by both the increase and reduction of pigmented cells (Rivera et al., 2001). Although chromatic aberrations have been of interest mainly for descriptive natural history purposes, it may provide interesting indications of phenotypic variability within species (Browder, 1972; Alho et al., 2010). Amphibian coloration is linked to chromatophore (specific epidermal cel1s) disposition. Chromatophores are pigment-containing cells, and are usually classified considering the chemical composition of the pigment granules and observing their colour under a white light. In amphibian skin, it is possible to find six types of chromatophores: the xanthophores containing yellow granules of carotenoids and pterins, the erythrophores containing red granules, the melanophores 
containing granules of melanin with a black or dark colour, the leucophores containing white granules and located just beneath melanophores, the cyanophores containing blue granules, and the iridophores containing crystals of guanine that have a silver or iridescent aspect (Duellman $\&$ Trueb, 1994). The distribution and occurrence of these chromatophores in the epidermis generally changes from species to species (Pough et al., 2016). There are several causes and typologies of alteration of individual coloration. All the possible cases were summarized by Brame \& Freytag (1963) and, more recently, by Dyrkacz (1981) and Rivera et al. (2001). In the case of albinism, animals completely lack dark pigmentation because of the total absence of all integumentary pigment. Complete albinos are identified by the white coloration of their skin and by their red irises. Other interesting cases of partial albinism may occur in individuals lacking all integumentary pigments, including eyes, except for some of the chromatophores. Leucistic individuals can be distinguished from albinos by their iris coloration, which remains normal. In contrast with albinos, leucistic animals do not seem to be as sensitive to sunlight exposure, and lack the difficulties with vision linked to missing pigments in the retinal epithelium (Dyrkacz, 1981). Albinism is a rare but reported hereditary anomaly in several urodele species (Dyrkacz, 1981). In Europe, one amphibian species is normally leucistic (Proteus anguinus), with the exception of the subspecies $P$. anguinus parakelj, which shows black pigments and developed eyes. Even if Italy has one of the highest numbers of amphibian species in Europe (Sillero et al., 2014) cases of albinism and leucism are quite rare and until now are documented only in 10 species (around 21\% of Italian species) (Pavesi, 1879; Lessona, 1880; Capanna, 1969; Capanna \& Foresti, 1974; Vanni \& Nistri, 1987; Corsini et al., 2002; Spadola \& Insacco, 2010; Modesti et al., 2011; Ambrogio \& Mezzadri, 2014; Crucitti et al., 2016). With this work, we report occurrence of albinism and leucism in six Italian species of amphibians, among which four are novel observation.

\section{MATERIALS AND METHODS}

We performed repeated field surveys from 2003 to 2016 in a context of different herpetological activities. We performed extensive surveys, mainly during spring and autumn seasons for numerous breeding sites and their surrounding areas in northern Italy and Sardinia, in order to observe both the adult and larval stages for each amphibian species. Moreover, we performed extensive samplings all year round on the Italian cave salamanders [genus Hydromantes; see Wake (2013) in caves and artificial tunnels (more than 5000 individuals observed)], as these species lack an aquatic larval stage (Lanza et al., 2006) and in underground environments their detectability is high (Lunghi et al., 2015). All encountered depigmented individuals were photographed and measured. Compatibly with our permissions, individuals were also reared for short periods in order to making detailed observations on the depigmentation features.

\section{RESULTS}

We found 5 partial albino individuals with xanthophores and 2 leucistic individuals of the species Salamandra salamandra, several leucistic individuals in Sardinian cave salamanders (10 Hydromantes sarrabusensis, $3 \mathrm{H}$. flavus and $3 \mathrm{H}$. supramontis), one leucistic larva of Triturus carnifex and a leucistic tadpole of Bufo viridis (all observations are summarized in Table 1, in which is also reported the region in which individuals were found).

Tab. 1 - Cases of albinism and leucism in Italian amphibians observed in this study.

\begin{tabular}{|c|c|c|c|c|}
\hline Species & Phase & Individuals & Chromatic aberration & Region of origin \\
\hline Salamandra salamandra & Larva & 3 & $\begin{array}{l}\text { Partial albinism with } \\
\text { xantophores }\end{array}$ & Lombardy \\
\hline Salamandra salamandra & $\begin{array}{l}\text { Larva followed after } \\
\text { metamorphosis }\end{array}$ & 1 & $\begin{array}{l}\text { Partial albinism with } \\
\text { xantophores }\end{array}$ & Lombardy \\
\hline Salamandra salamandra & Adult & 1 & Leucism & Lombardy \\
\hline Salamandra salamandra & Adult & 1 & Leucism & South Tyrol \\
\hline Triturus carnifex & Larva & 1 & Leucism & Lombardy \\
\hline Hydromantes sarrabusensis & Adults/subadults & $6 / 4$ & Leucism & Sardinia \\
\hline Hydromantes flavus & Adult & 3 & Leucism & Sardinia \\
\hline Hydromantes supramontis & Adult & 3 & Leucism & Sardinia \\
\hline Bufo viridis & Tadpole & 1 & Leucism & Lombardy \\
\hline
\end{tabular}




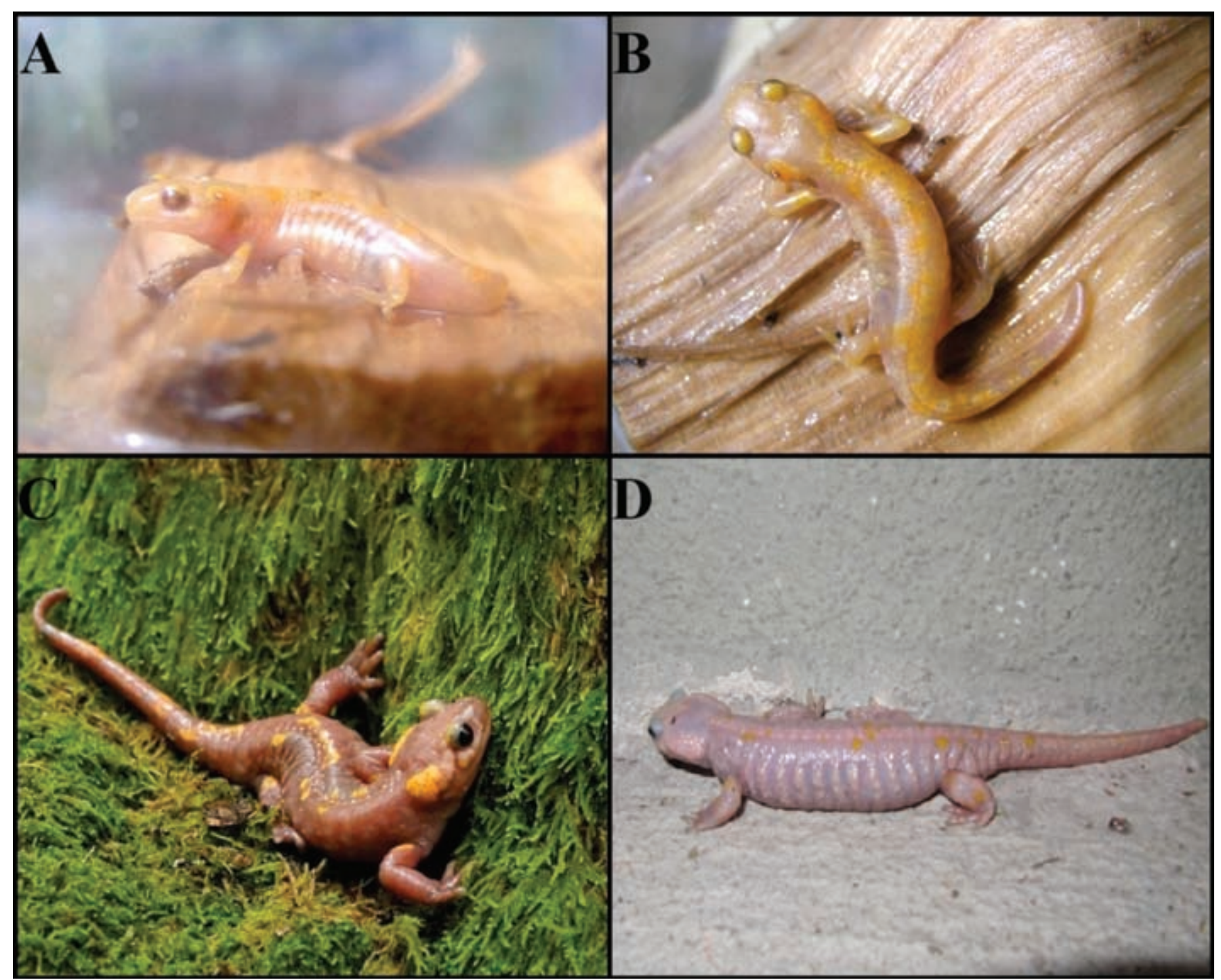

Fig. 1 - Fire salamander (Salamandra salamandra) individuals showing albinism and leucism. A) metamorphosed albino with xanthophores found in 2013; B) metamorphosed albino with xanthophores found in 2014; C, D) leucistic adults.

For S. salamandra, in March 2013 we found one albino larva with xanthophores (Fig. 1A) of $26 \mathrm{~mm}$ of total length, over 56 total larvae were sampled in the southern Como district. In the same locality 3 albino larvae with xanthophores amongst 37 larvae sampled were found in April 2014 (Fig. 1B); total length of all the three larvae was $31 \mathrm{~mm}$. The other albino with xanthophores was found at larval stage on November 25 in a south-eastern area of Como district. The individual (40 $\mathrm{mm}$ long upon discovery) was found in a small spring in a broadleaved wood with prevalence of alders and oaks (Fig. 2A). The spring feeds a small creek where other normally pigmented larvae occur. The integumentary pigments except for some tiny yellow spots were absent from the head, limbs and tail. Eyes were markedly red indicating a lack of pigment in the iris. The larva was collected in the context of a three-year long ethological study (Manenti et $a l ., 2013$ ) and reared in controlled conditions (authorization by Lombardy Region, p. n. F12013.0002091; rearing conditions are described in Manenti et al. (2016). During the last larval stage the individual developed a number of large yellow dorsal spots (Fig. 2B-D) that became more defined after the metamorphosis, which occurred on February 22, 2015, at a total length of $64 \mathrm{~mm}$ (Fig. 2E). A leucistic adult fire salamander (total length $15 \mathrm{~cm}$ ) was found on September 2015 in the northern Como district active in a wood at an altitude of $814 \mathrm{~m}$ a.s.l (Fig. 1C). Another leucistic fire salamander was found in two consecutive years (September 2009 and September 2010) in Trento district, at $1,057 \mathrm{~m}$ a.s.l (Fig. 1D). The survey was done near a house surrounded by hay meadows (Arrhenatherum $s p$. with umbelliferous plants), vegetable gardens and woods with ashes and maples. The area has small wells and woodsheds as well as ephemeral ponds in the surrounding areas while streams occur farther from the site.

For Hydromantes sarrabusensis, several individuals showing different levels of leucism were found in the Cagliari district. The site was checked five times (from April to October 2015) and the maximum number of individuals with anomalous coloration observed during one survey was 10; we observed leucism only in adults and sub-adults. 


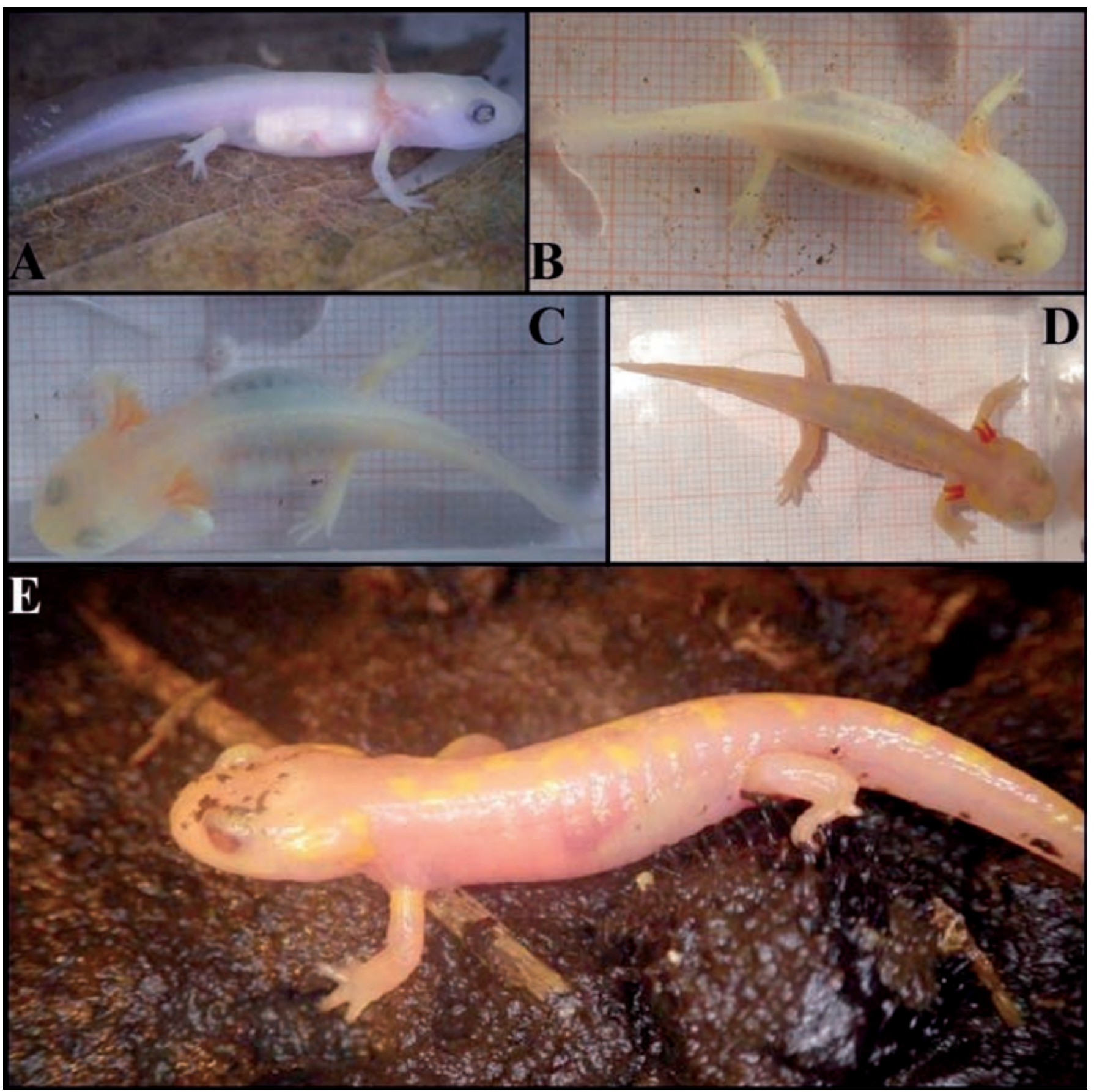

Fig. 2 - Different stages of larval development and metamorphosis of an albino fire salamander larva with xanthophores. A) Moment of collection in November 2014 (40 mm of total length); B) December 2014; C) January 2015; D) pre-metamorphosis on February 15, 2015; E) just after metamorphosis on February 22, 2015.

The complete leucistic individuals showed pale-pink coloration with white spots (Fig. 3A). For H. flavus, during a cave survey in eastern area of Nuoro district, in April 2016 we found three partial leucistic individuals. These individuals showed a pale/pink coloration of both limbs and tail, while the color of the back was light-grey: in two of them yellow spots where still visible, while in the third spots were almost white (Fig. 3B). For H. supramontis, in two caves of southern area of Nuoro district surveyed during May 2016, we found three leucistic individuals: one was totally pale, showing only very light yellow spots (Fig. 3C). Transparence of the skin made some internal structures and organs visible, such as the back bone and blood vessels.

A leucistic Triturus carnifex was found in April 2003 in Milan district (Fig. 4A). The individual was a large larva that likely overwintered in a large source that continuously retained water during winter. The leucistic tadpole of Bufo viridis was found in April 2016 in the district of Milan (Fig. 4B). It was in an artificial pool together with hundreds of normally pigmented conspecifics. 


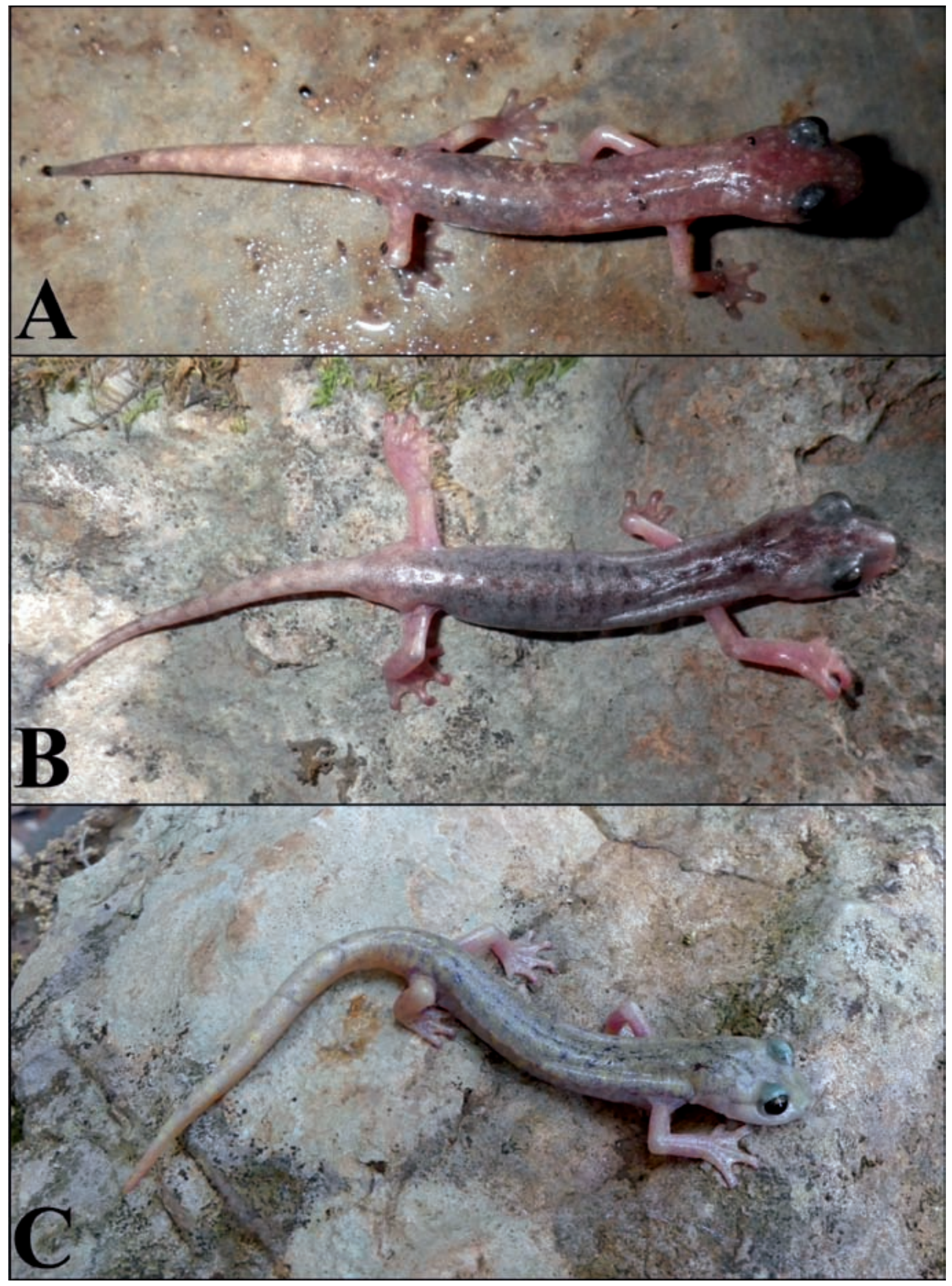

Fig. 3 - Leucistic individual of Hydromantes sarrabusensis (A), H. flavus (B) and H. supramontis (C). 


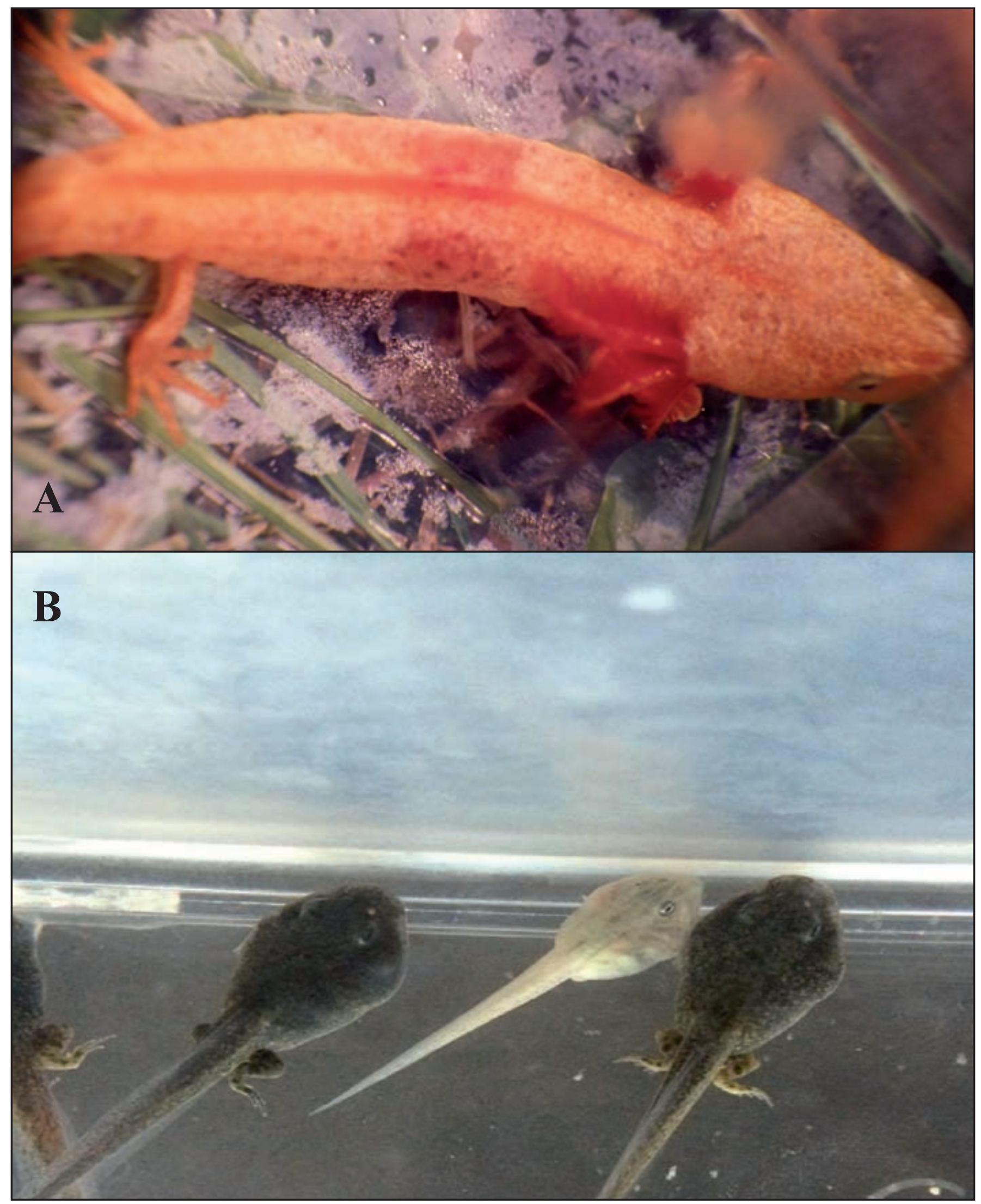

Fig. 4 - Leucistic larvae of Triturus carnifex (A) and Bufo viridis (B). 


\section{DISCUSSION AND CONCLUSIONS}

In this work we report 24 cases of albinism and leucism in Italian amphibians. About $79 \%$ of the cases involve adults and sub-adults, while the remaining $21 \%$ deals with larvae or tadpoles. This proportion is unexpected as viability of albinos is generally reduced compared to the wild type (Browder, 1972; Lira et al., 2016); however, if we consider only species which undergo metamorphosis, the number of albino/leucistic larvae is higher than adults (respectively 6 for larvae and 2 for adults). Within our observations, 16 individuals belong to the genus Hydromantes: these animals are characterized by direct development so they lack a larval stage (Lanza et al., 2006). Moreover, Hydromantes species often exploit underground environments to avoid unsuitable epigean environmental conditions (Lunghi et al., 2015). Thus, the short time in which these animals are most vulnerable (juvenile stage) and the subterranean habitat in which there are few predators, may reduce cave salamander mortality. The most abundant chromatic aberrations that we recorded were the less extreme ones, such as leucism $(83 \%)$; while the albinism, even partial, remains rare $(17 \%)$.

\section{Acknowledgments}

Enrico Lunghi is supported by The Mohamed bin Zayed Species Conservation Fund, The National Speleological Society and Instrumentl. Studies on Hydromantes was conducted under Ministerial Authorization (9384/PNM of 12/05/2015).

\section{REFERENCES}

Alho J.S., Herczeg G., Söderman F., Laurila A., Jönsson K.I. \& Merilä J., 2010 - Increasing melanism along a latitudinal gradient in a widespread amphibian: local adaptation, ontogenic or environmental plasticity? BMC Evolutionary Biology, 10: 317.

Ambrogio A. \& Mezzadri S., 2014 - Girini d'Italia, Tadpoles of Italy. Gavia Edizioni, Piacenza.

Barbagli F. \& Violani C., 2004 - Breve storia dell'erpetologia lombarda. In: Atlante degli Anfibi e dei Rettili della Lombardia. Bernini F., Bonini L., Ferri V., Gentilli A., Scali S. (eds.). Monotipia Cremonese, Cremona, 13-33.

Brame A.H. \& Freytag G.E., 1963 - Ein Halbalbino von Chioglossa lusitanica. Zoologischer Garten, 27: 130-131.

Browder L.W., 1972 - Genetic and embryological studies of albinism in Rana pipiens. Journal of Experimental Zoology, 180: 149-155.

Capanna E., 1969 - Albinismo parziale in una popolazione insulare di Discoglossus sardus Tschudi. Bollettino di Zoologia, 36: 135-141.

Capanna E. \& Foresti V., 1974 - Analisi dello sviluppo di un mutante semiabino di Triturus cristatus / Developmental analysis of a semialbino mutant of Triturus cristatus. Rivista di Biologia, 67: 19-45.

Corsini S., Ferretti M., Pastorino M.V., Prati A., Alario G. \& Salvidio S., 2002 - Speleomantes ambrosii
(Ambrosi's Cave Salamander). Albinism. Herpetological Review, 33 (2): 123.

Crucitti P., Doglio S. \& Tringali L., 2016 - Depigmented phenotypes inside a Salamandrina perspicillata population of the Campagna Romana (Latium, Italy). Natural History Sciences, 3 (1), 15-20.

Duellman W.E. \& Trueb L., 1994 - Biology of Amphibians. Johns Hopkins University Press, Baltimore, MD.

Dyrkacz S., 1981 - Recent instances of albinism in North American amphibians and reptiles. Herpetological circular, 11: 1-31.

Lanza B., Pastorelli C., Laghi P. \& Cimmaruta R., 2006 A review of systematics, taxonomy, genetics, biogeography and natural history of the genus Speleomantes Dubois, 1984 (Amphibia Caudata Plethodontidae). Atti del Museo Civico di Storia Naturale di Trieste, 52: 5-135.

Lessona M., 1880 - Dello albinismo nei girini della Rana temporaria Linn. Atti dell'Accademia delle Scienze di Torino, A. XVI, 94-98.

Lira A.F.A., Pordeus L.M. \& Albuquerque C.M.R., 2016 - Leucism in Tityus pusillus (Scorpiones: Buthidae): Report of a rare event in scorpions. Journal of Arachnology, 44: 245-246.

Lunghi E., Manenti R. \& Ficetola G.F., 2015 - Seasonal variation in microhabitat of salamanders: environmental variation or shift of habitat selection? Peer $J, 3$ : e1122.

Manenti R., Denoël M. \& Ficetola G.F., 2013 - Foraging plasticity favours adaptation to new habitats in fire salamanders. Animal Behaviour, 86: 375-382.

Manenti R., Melotto A., Denoël M. \& Ficetola G.F., 2016 - Amphibians breeding in refuge habitats have larvae with stronger anti-predatory responses. Animal Behaviour, 118: 115-121.

Modesti A., Aguzzi S. \& Manenti R., 2011 - A case of complete albinism in Lissotriton vulgaris meridionalis. Herpetology Notes, 4: 395-396.

Pavesi P., 1879 - Sull'albinismo nei batraci. Rendiconti R. Istituto lombardo di Scienze e Lettere s. 2, 12: 528-535.

Pough F.H., Andrews R.M., Crump M.L., Savitzky A.H., Wells K.D. \& Brandley M.C., 2016 - Herpetology (4rd Edition). Sinauer Associates, Inc., Sunderland, MA.

Rivera X., Arribas O. \& Martí F., 2001 - Revisión de anomalias pigmentarias en los anfibios de la Península Ibérica y de Europa. Butlletí de la Societat Catalana d'Herpetologia, 15: 59-75.

Sillero N., Campos J., Bonardi A., Corti C., Creemers R., Crochet P.A., Isailović J.C., Denoël M., Ficetola G.F., Gonçalves J., Kuzmin S., Lymberakis P., de Pous P., Rodríguez A., Sindaco R., Speybroeck J., Toxopeus B., Vieites D.R. \& Vences M., 2014 Updated distribution and biogeography of amphibians and reptiles of Europe. Amphibia-Reptilia, 35: $1-31$.

Spadola F. \& Insacco G., 2010 - Incomplete albinism in Discoglossus pictus (Otth, 1837). Acta Herpetologica, 5 (2): 245-253. 
Vanni S. \& Nistri A., 1987 - Brevi note su alcuni esemplari anomali conservati nella collezione erpetologica del Museo Zoologico « La Specola » dell'Università di Firenze. Atti Museo Civico di Storia Naturale di Grosseto, 11/12: 85-87.

Vanni S. \& Zuffi M.A.L., 2001 - Stato delle conoscenze anatomiche e fisiologiche in Salamandrina terdigitata (Lacépède, 1788) (Amphibia Caudata Salamandridae), Atti $3^{\circ}$ Congresso nazionale SHI (Pavia, 2000). Pianura, Pavia, 95-100.

Wake D.B., 2013 - The enigmatic history of the European, Asian and American plethodontid salamanders. Amphibia-Reptilia, 34: 323-336. 